\title{
Understanding Covid-19 Management Process in Health Care Facilities Using Functional Resonance Analysis Method
}

\author{
Emin Tarakç1 ${ }^{1} \quad$ Müge Ensari Özay ${ }^{2 *} \quad$ Ahmet Ebrar Sakallı $^{3} \quad$ Emine Can ${ }^{4}$ \\ 1.Department of Occupational Health and Safety, Istanbul Medeniyet University, Dumlupinar D100 Karayolu \\ No:98, 34720 Kadıköy, Istanbul, Turkey \\ 2.Department of Occupational Health and Safety, Uskudar University, Mimar Sinan, Selmani Pak Cd, 34672 \\ Üsküdar, Istanbul, Turkey \\ 3.Department of Occupational Health and Safety, Istanbul Aydın University, Beşyol, İnönü Cd. No:38, 34295 \\ Küçükçekmece, Istanbul, Turkey \\ 4.Department of Physics Engineering, Faculty of Engineering, Istanbul Medeniyet University, Dumlupinar D100 \\ Karayolu No:98, 34720 Kadıköy, Istanbul, Turkey
}

\begin{abstract}
COVID-19 was identified in Wuhan, China, in December of 2019. Afterwards, it spreads all over the World and causes many difficulties in health management in many countries. Many risk analysis methods have been applied to control and minimize contamination risks. This study aims to understand the COVID-19 management process in health care facilities using the Functional Resonance Analysis Method (FRAM) to facilitate the safety analysis, taking account of the system response to different operating conditions and various risks. The hospital process of COVID-19 patient is examined in three public and one private hospital in Istanbul/Turkey. The information is taken with teleconference meetings over 34 hours with 16 doctors and 12 nurses during a month. The model is applied by "FRAM Model Visualizer" to determine potential couplings between the functions and their potential impact on the hospital process. Fourteen functions are identified to analyze the hospital process of a patient, and multiple scenarios are developed with consideration for the progress conditions of the system. It has been concluded that FRAM does not remain at the conceptual level with application studies, but it is very suitable for many complex systems such as case analyzes such as pandemic and disaster scenarios.
\end{abstract}

Keywords: COVID-19, pandemic, Functional resonance analysis method, Health care facilities

DOI: $10.7176 / \mathrm{JHMN} / 80-13$

Publication date:September $30^{\text {th }} 2020$

\section{Introduction}

Coronavirus outbreak is an ongoing pandemic and over 12,1 million people across the two hundred countries have been infected according to the last updates of the World Health Organization (WHO, 2020a). Approximately 552 thousand confirmed deaths among the case are reported by WHO. Humanity has faced a severe pandemic through the history that spreads rapidly all over the earth. If a defined brand new virüs is able to spread from person to person while infecting the contacts quickly with a sustained and efficient way, then it is called a pandemic (WHO, 2020). The novel coronavirus (2019-nCoV) fulfils all those definitions strongly. At the end of the year 2019, Wuhan city of Chine cradled the first case of the novel coronavirus. Now from Europe to America, its deadly effects threaten the whole world. The WHO named the 2019-nCoV epidemic disease on February 11, 2020, as coronavirus disease (Covid-19). 2019-nCoV is a new member of the Severe Acute Respiratory Syndrome coronavirus family (SARS-CoV) and labelled as SARS-CoV-2 (WHO, 2020b).

The first diagnosis of COVID-19 was made on March 10, 2020, in Turkey (Official statement of Republic of Turkey Ministry of Health). As of 8 July 2020, more than 208,000 cases of COVID-19 have been reported and resulting in more than 5,200 deaths (Republic of Turkey Ministry of Health, 2020).

Epidemic diseases have many effects on the economy, psycho-social risk factors, business world and education system. Outbreaks have many significant effects on the economy, such as health care expenses, unemployment, production decrease uncertainty (Smith et al. 2019). Emergencies, like natural disasters, industrial incidents, infectious diseases and terrorist attacks, etc., often cause losses of life or injury, property damages, social and economic disruptions or environmental degradations. When an emergency occurs, the relevant management personnel or decision-makers (DMs) need to decide what actions to take instantly to mitigate or minimize the adverse effects. Usually, the decision-making problems in emergency response are complicated due to the limited decision data and possible evolvement of emergency scenarios. Therefore, how to select an effective response action in the earlier stage of emergency is an important research topic in emergency management (Liu et al. 2014).

Several mathematical models and risk analysis methods have been developed and applied for many emergencies. The Functional Resonance Analysis Method (FRAM) is one of risk analysis methods and is based on a complex non-linear model, assuming that accidents are the result of unexpected combinations (resonance) of normal variability, couplings between functions that resonate, but that are also not random, although it cannot 
be attributed to a simple combination linear of linked causes (Hollnagel, 2012). The FRAM tries to find causes of unfavourable events because it takes for granted that knowledge of reasons is necessary to prevent things from going wrong in the future. The purpose of the FRAM is to analyze how something has been done, how something is done, or how something could be done to represent it reliably and systematically, using a welldefined format (Hollnagel, Hounsgaard, Colligan, 2014; Kaya, Ovali, Ozturk, 2019).

Thus, the present study aimed to identify appropriate COVID 19 management processes in health care facilities using the Functional Resonance Analysis Method. This process might be to strengthen the desired performance of the Hospital process of COVID-19 patients.

\section{Method}

In this study, the working cluster is composed of 3 public and 1 private hospitals in Istanbul/Turkey. The hospital process of COVID-19 patient was examined by applying the FRAM. All information of the hospital process was taken with teleconference meetings which were held over 34 hours with 16 doctors ( 4 doctors from each hospital) and 12 nurses ( 3 nurses from each hospital) during a month. The FRAM model is applied by "FRAM Model Visualizer" to observe and analyze help to control the spreading speed of pandemic in health facilities.

\subsection{The Functional Resonance Analysis Method}

The FRAM involves the four steps proposed by (Hollnagel, 2014) : Hollnagel First step is identification of the system's functions. Second step is identification of performance variability. Third step is aggregation of variability. Fourth step is management of variability. In the first step, the functions of the system were identified. Functions in the FRAM can be defined either as foreground functions or background functions. In the second step, the variability of each function was determined. In this study, the variability of a function's output was defined in terms of time (too early, too late, on time or not at all) and precision (precise, acceptable, or imprecise). In the third step, it was analysed that how system performance affects and is affected by the coupling variability. Lastly, in the fourth step, possible ways were proposed to monitor uncontrolled performance variability.

\section{Results}

In this study, the hospital processes of COVID-19 patients in Istanbul/Turkey were examined after the announcement of the pandemic. FRAM stages were applied step by step. The functions were generated according to the 6 aspects as input, output, precondition, resource, control and time. The aspects of a sample function "The patient is taken into service" has 5 inputs, 2 outputs, 2 preconditions, 5 controls a done time aspect and was described at Table 1 . At the second step, the variability of each function was determined, as shown in Table 2.

Table 1. An example of identified functions of the system

\begin{tabular}{|l|l|}
\hline Name of the Function & F11. The patient is taken into service \\
\hline Description & $\begin{array}{l}\text { The patient, who comes to the hospital with the suspicion of Covid-19, is directed to } \\
\text { the service or intensive care unit after the necessary tests are made in the triage area. } \\
\text { Depending on the condition of the patient, the patient is taken to the service or } \\
\text { intensive care. PCR test is performed, and the result is waited for a diagnosis. } \\
\text { According to the result, the patient is treated. Patients whose condition worsens are } \\
\text { taken to the intensive care unit. The recovered patients are discharged. }\end{array}$ \\
\hline Aspect & $\begin{array}{l}\text { Description of Aspect } \\
\text { Inputs }\end{array}$ \\
$\begin{array}{l}\text { Patient who has doubt of COVID19 comes to hospital } \\
\text { The doctor examines the patient } \\
\text { The result of the diagnosis is waited } \\
\text { Test result is positive } \\
\text { Test result is negative }\end{array}$ \\
\hline Outputs & $\begin{array}{l}\text { The patient is taken to intensive care unit } \\
\text { The patient is discharged from hospital }\end{array}$ \\
\hline Preconditions & $\begin{array}{l}\text { Risk degree of patient } \\
\text { The course of disease }\end{array}$ \\
\hline Resources & $\begin{array}{l}\text { The Ministry of Health and WHO instructions and standards } \\
\text { Treatment of the patient takes place in isolated services }\end{array}$ \\
\hline
\end{tabular}




\begin{tabular}{|l|l|}
\hline Name of the Function & F11. The patient is taken into service \\
\hline Controls & All instructions and procedures are followed \\
& The patient is taken to the units from the areas determined for the pandemic \\
& $\begin{array}{l}\text { Personal protective equipment (PPE) is clothed to all healthcare professionals and } \\
\text { patients } \\
\text { Only employee in charge can enter } \\
\\
\text { Droplet isolation is applied }\end{array}$ \\
\hline Time & $5-10$ day \\
\hline
\end{tabular}

Table 2. Variabilities of each function

\begin{tabular}{|c|c|c|c|c|}
\hline $\begin{array}{l}\text { Function } \\
\text { No }\end{array}$ & Function & $\begin{array}{l}\text { Variabi } \\
\text { lity No }\end{array}$ & Variability & Explanation \\
\hline \multirow[t]{2}{*}{ F1 } & \multirow{2}{*}{$\begin{array}{l}\text { Epidemic } \\
\text { disease begins }\end{array}$} & F1V1 & Known virus & Treatment method is known \\
\hline & & F1V2 & Unknown virus & Treatment method is unknown \\
\hline \multirow[t]{3}{*}{ F2 } & \multirow{3}{*}{$\begin{array}{l}\text { Patient who has } \\
\text { doubt } \\
\text { COVID19 } \\
\text { comes } \\
\text { hospital }\end{array}$} & F2V1 & $\begin{array}{ll}\text { Patient } & \text { comes } \\
\text { ambulance }\end{array}$ & Severe disease / Emergency \\
\hline & & F2V2 & $\begin{array}{l}\text { Patient comes with } \\
\text { companion }\end{array}$ & \\
\hline & & F2V3 & Patient comes his/her own & \\
\hline \multirow[t]{2}{*}{ F5 } & \multirow{2}{*}{$\begin{array}{l}\text { The patient is } \\
\text { taken to the } \\
\text { triage area }\end{array}$} & F5V1 & Age of patient & Risk degree of patient is checked \\
\hline & & F5V2 & Chronic diseases of the patient & Risk degree of patient is checked \\
\hline \multirow[t]{3}{*}{ F6 } & \multirow{3}{*}{$\begin{array}{l}\text { The doctor } \\
\text { examines the } \\
\text { patient }\end{array}$} & F6V1 & Severe disease & Risk degree of patient is checked \\
\hline & & F6V2 & $\begin{array}{l}\text { The patient's condition is } \\
\text { uncertain }\end{array}$ & Risk degree of patient is checked \\
\hline & & F6V3 & Benign disorder & Risk degree of patient is checked \\
\hline \multirow[t]{2}{*}{ F7 } & \multirow{2}{*}{$\begin{array}{l}\text { Tests are made } \\
\text { to the patient for } \\
\text { diagnosis }\end{array}$} & F7V1 & Diagnosis could be made & $\begin{array}{l}\text { The test result will be determined } \\
\text { within } 48 \text { hours }\end{array}$ \\
\hline & & F7V2 & Diagnosis could not be made & Monitoring/making new tests \\
\hline \multirow[t]{2}{*}{ F8 } & \multirow{2}{*}{$\begin{array}{l}\text { The result of the } \\
\text { diagnosis is } \\
\text { waited }\end{array}$} & F8V1 & The patient is in the hospital & Risk degree of patient is checked \\
\hline & & F8V2 & $\begin{array}{l}\text { The patient is discharged from } \\
\text { hospital }\end{array}$ & Risk degree of patient is checked \\
\hline \multirow[t]{2}{*}{ F9 } & \multirow{2}{*}{$\begin{array}{l}\text { Test result was } \\
\text { positive }\end{array}$} & F9V1 & Severe disease & Risk degree of patient is checked \\
\hline & & F9V2 & Benign disorder & Risk degree of patient is checked \\
\hline \multirow[t]{2}{*}{ F10 } & \multirow{2}{*}{$\begin{array}{l}\text { Test result was } \\
\text { negative }\end{array}$} & F10V1 & Patient is monitored & Risk degree of patient is checked \\
\hline & & F10V2 & $\begin{array}{l}\text { The patient is discharged from } \\
\text { hospital }\end{array}$ & Risk degree of patient is checked \\
\hline \multirow[t]{2}{*}{ F11 } & \multirow{2}{*}{$\begin{array}{l}\text { The patient is } \\
\text { taken into } \\
\text { service }\end{array}$} & F11V1 & $\begin{array}{l}\text { The patient responds positively } \\
\text { to treatment }\end{array}$ & $\begin{array}{l}\text { The patient is discharged from } \\
\text { hospital }\end{array}$ \\
\hline & & F11V2 & $\begin{array}{l}\text { The patient's condition goes } \\
\text { worst }\end{array}$ & $\begin{array}{l}\text { The patient is taken to intensive } \\
\text { care unit }\end{array}$ \\
\hline \multirow[t]{2}{*}{ F12 } & \multirow{2}{*}{$\begin{array}{l}\text { The patient is } \\
\text { taken to } \\
\text { intensive care } \\
\text { unit }\end{array}$} & F12V1 & $\begin{array}{l}\text { The patient responds positively } \\
\text { to treatment }\end{array}$ & $\begin{array}{l}\text { The patient is discharged from } \\
\text { hospital }\end{array}$ \\
\hline & & F12V2 & The patient is died & \\
\hline \multirow[t]{2}{*}{ F14 } & \multirow[t]{2}{*}{$\begin{array}{l}\text { The patient is } \\
\text { discharged from } \\
\text { hospital }\end{array}$} & F14V1 & $\begin{array}{l}\text { The patient remains isolated at } \\
\text { home for a certain period of time }\end{array}$ & $\begin{array}{l}\text { Department of public health } \\
\text { regularly checks and monitors the } \\
\text { isolated patient }\end{array}$ \\
\hline & & F14V2 & $\begin{array}{l}\text { The patient returns to normal life } \\
\text { controllably }\end{array}$ & PPE use/stay away from the crowd \\
\hline
\end{tabular}

In the third step, it was examined at specific instantiations of the model to understand how the variability of the functions may become coupled and determine whether this can lead to unexpected outcomes. For instance, as shown in Table 3, the first function (epidemic disease begins) has 2 variabilities. The first variability is that an unknown virus is detected. The second variability is that a known virus is detected. All these variabilities affect function in terms of "imprecise" precision, and that's why all these variabilities directly affect declaration of a pandemic. Another example, output of the first function (WHO announces pandemic) has four variabilities (too early, too late, on time or not at all). All these variabilities affect the function's output in terms of time.

In the final step, it was analyzed to manage the possible occurrences of uncontrolled performance 
variability that have been found by the preceding steps. Risk degrees of the patient and the course of disease used in the tables are determined according to the Ministry of Health of the Turkish Republic guidance [3] and definitions. Risk degrees of the patient used in functions are specified as high, medium and low risk. The course of disease used in determining functions is as very heavy, heavy and low/average level.

The FRAM was used to determine potential couplings between the functions and their potential impact on the hospital process (Fig. 1). Fourteen foreground functions are identified to analyze the hospital process of a patient and examined after the announcement of the pandemic (Table 1). Multiple scenarios were developed with consideration for the progress conditions of the system (Table 3).

Table 3. Scenarios that increase the risk of transmission and spread of the epidemic

\begin{tabular}{|c|c|c|c|}
\hline $\begin{array}{l}\text { Scenario } \\
\text { No }\end{array}$ & Scenario & Variability & Effect of Variability \\
\hline \multirow[t]{2}{*}{ 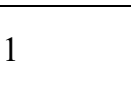 } & \multirow{2}{*}{ Epidemic disease begins } & Known virus & \multirow{2}{*}{ WHO announces pandemic } \\
\hline & & Unknown virus & \\
\hline \multirow{4}{*}{2} & \multirow{4}{*}{ WHO announces pandemic } & Too early & \multirow{4}{*}{$\begin{array}{l}\text { Hospital management and } \\
\text { organization }\end{array}$} \\
\hline & & On-time & \\
\hline & & Too late & \\
\hline & & Not at all & \\
\hline \multirow{2}{*}{3} & \multirow{2}{*}{$\begin{array}{l}\text { Hospital management and } \\
\text { organization }\end{array}$} & Ready for a pandemic scenario & \multirow{2}{*}{ All subsequent processes } \\
\hline & & Not ready for a pandemic scenario & \\
\hline \multirow{3}{*}{4} & \multirow{3}{*}{ Process of hospital arrival } & Patient comes by ambulance & \multirow{3}{*}{$\begin{array}{l}\text { The risk of transmission } \\
\text { and } \\
\text { spread of the epidemic }\end{array}$} \\
\hline & & Patient comes with a companion & \\
\hline & & Patient comes his/her own & \\
\hline \multirow[b]{2}{*}{5} & \multirow{2}{*}{$\begin{array}{l}\text { Identification process of } \\
\text { the patient contact chain }\end{array}$} & Timing & \multirow{2}{*}{$\begin{array}{l}\text { The risk of transmission } \\
\text { and } \\
\text { spread of the epidemic }\end{array}$} \\
\hline & & Precision & \\
\hline 6 & $\begin{array}{l}\text { The sensitivity of the } \\
\text { diagnostic test }\end{array}$ & 70 percent sensitivity & The result of the diagnosis \\
\hline \multirow{3}{*}{7} & \multirow{3}{*}{ Risk degrees of patient } & High risk & \multirow{3}{*}{ Identification of diagnosis } \\
\hline & & Medium risk & \\
\hline & & Low risk & \\
\hline \multirow{3}{*}{8} & \multirow{3}{*}{ The course of disease } & Very heavy level & \multirow{3}{*}{ Identification of diagnosis } \\
\hline & & Heavy level & \\
\hline & & Low / average level & \\
\hline
\end{tabular}

FRAM model of the hospital process of COVID-19 patient was applied by FRAM Visualizer, as shown in Figure 1. Observations, analyzes and outcomes of application have shown that there are essential critical paths and factors in the spreading speed of pandemic in health facilities. Findings demonstrate that critical path affecting the spreading speed of pandemic should be detected accurately and timely so that the pandemic is announced at the right time.

Another significant factor is that health facilities and all relevant elements have to be prepared for a possible pandemic and disaster scenario. Thus, take control of pandemic can be ensured with involved organization, management policies and resources. For example, the announcement of a pandemic in the second scenario is critical in the FRAM model. It directly affects all other processes and that all processes depend on the pandemic announcement. As the pandemic cannot be implemented after the announcement of the controls, precautions and policy time, an increase in the speed of the epidemic and cases can be observed. 


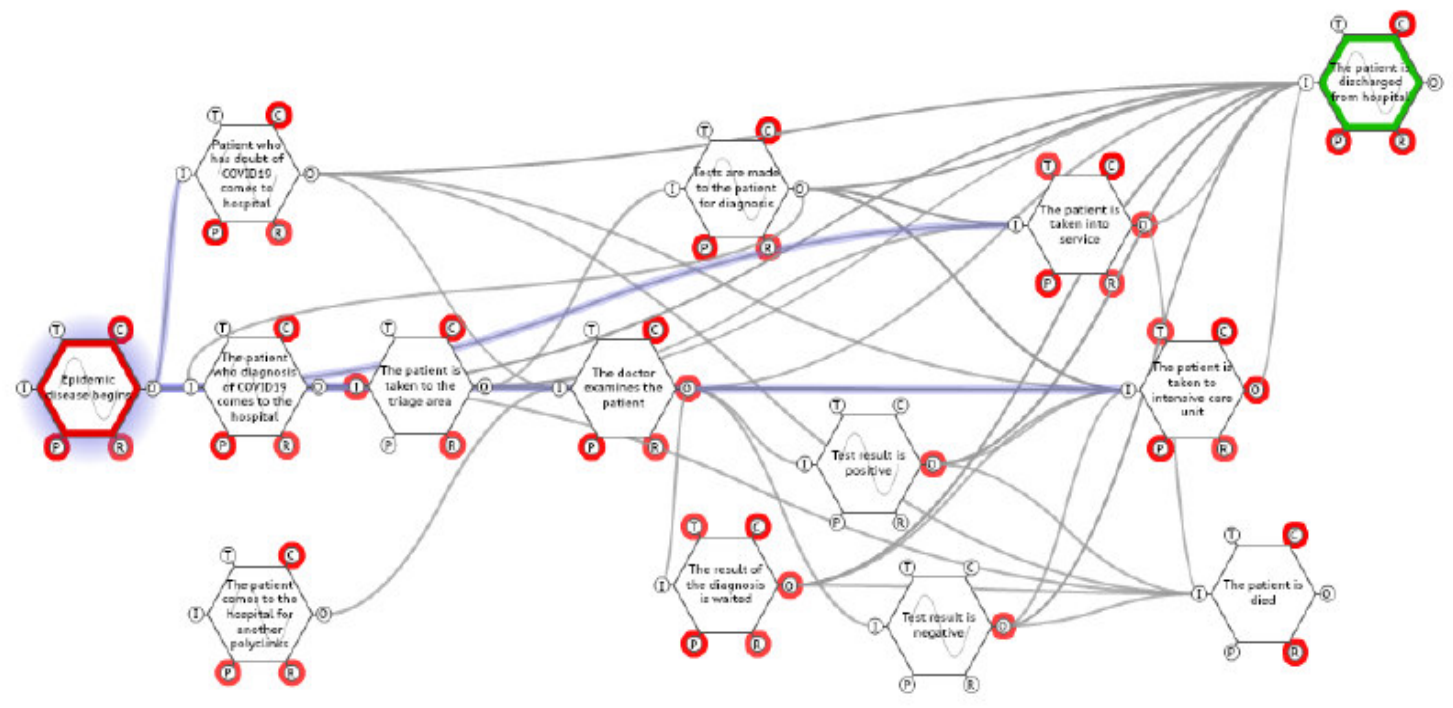

Figure 1. FRAM model of the hospital process of a patient

\section{Discussion}

In this study, hospital processes of COVID-19 patient in Istanbul/Turkey were investigated with FRAM to help better understanding and controlling the spread of pandemics in health care facilities.

The FRAM try to find causes of unfavourable events because it takes for granted that knowledge of causes is necessary to prevent things from going wrong in the future (Hollnagel, 2012). This is based on that if there is an effect and then there must also be a cause. FRAM helps to understand a difficult and complex system like a pandemic. It provides a better understanding and management of the process by linking all processes and components. For instance, as shown in Table 1, the description of the first function is "Epidemic disease begins". The output of this function is "WHO announce pandemic". Preconditions of this function are "the emergence of a disease in which the population has not previously been exposed", "disease-causing the disease to be transmitted to humans and cause a dangerous disease" and "easy and continuous spread of the disease factor among people". The control functions are "pandemic policies and emergency scenarios begin to apply", "governments carry out communication, coordination and cooperation against pandemic", "emergency and pandemic management scenarios and organization are created", "organization and planning of healthcare professionals to be assigned to the pandemic (rotation, backup, emergency, etc.)", "organize and provide accommodation, transportation, food service for healthcare professionals", "all employees are informed about the pandemic" and "all employees are provided with PPE training and equipment".

Identifying all functions and their aspects helps to understand the process of COVID-19 management in the hospital. Thus it provides to establish the connection between the inputs and outputs of the process and to find the necessary controls for each process.

As shown in Table 2, the performance variability of the system is identified. For instance, variabilities of the first function are "known virus" and "unknown virus". Contrary to an unknown virus, the known virus has treatment method. Another example, variabilities of the second function are "patient comes by ambulance", "patient comes with a companion" or "patient comes his/her own". All these variabilities affect the spreading speed of pandemic in health facilities. That's why it is so significant to identify the system's function, aspects and performance variability.

Scenarios that increase the risk of transmission and spread of the epidemic is developed As shown in Table 3. For instance, WHO can announce pandemic too early, on time, too late or not at all.

As a result of FRAM visualizer application, connections and loops of all processes are demonstrated in Figure 2. As seen from the loop, accurate and timely reporting of diseases and deaths affects the announcement of the pandemic. Unless pandemic is announced on time, it affects the rate of spread of the epidemic. Thus the announcement of the pandemic on time is a critical path to control the spread of the epidemic. By using FRAM, the process of the system is examined concerning each other, and the necessary controls for the whole process are defined. Therefore FRAM helps to enable the pandemic to be managed properly in hospitals.

\section{Conclusion}

Infectious diseases from animal to human have emerged and continue to spread at an increasing rate. COVID-19 
has also demonstrated how quickly modern outbreaks can become pandemics. All state policies, related institutions and health facilities should be ready against an epidemic in the future. This study shows that the FRAM could understand the process of hospital management to get prepared against a possible pandemic scenario. Therefore, controlling these issues and ensuring safe conditions are mutual tasks of humanity.

\section{Acknowledgements}

The authors would like to express their gratitude to the healthcare professionals who contributed to the study and in particular, Dr Ahmet Şükrü KULUALP. The authors would also like to offer their special thanks to Mathilde A. Rodrigues for her valuable comments.

\section{References}

Hollnagel, E. (2012). FRAM, the functional resonance analysis method: modelling complex socio-technical systems. Ashgate Publishing, Ltd..

Hollnagel, E., Hounsgaard, J., \& Colligan, L. (2014). FRAM-the Functional Resonance Analysis Method: a handbook for the practical use of the method. Centre for Quality, Region of Southern Denmark.

Kaya, G. K., Ovali, H. F., \& Ozturk, F. (2019). Using the functional resonance analysis method on the drug administration process to assess performance variability. Safety Science, 118, 835-840.

Liu, Y., Fan, Z. P., Yuan, Y., \& Li, H. (2014). A FTA-based method for risk decision-making in emergency response. Computers \& Operations Research, 42, 49-57.

Republic of Turkey Ministry of Health, (2020). COVID-19(SARS-COV-2 infection COVID-19 (SARS-CoV-2 INFECTION) Guide. [Online] Available: https://covid19bilgi.saglik.gov.tr/depo/rehberler/COVID19_Rehberi.pdf (May 10, 2020).

Smith, K. M., Machalaba, C. C., Seifman, R., Feferholtz, Y., \& Karesh, W. B. (2019). Infectious disease and economics: The case for considering multi-sectoral impacts. One Health, 7, 100080.

World Health Organization(WHO), (2020a). [Online] Available: https://www.who.int/ (May 3, 2020).

World Health Organization (WHO), (2020b). Director-General's remarks at the media briefing on 2019-nCoV. 2020 February 11. [Online] Available: https://www.who.int/dg/speeches/detail/who-director-general-sremarks-at-the-media-briefing-on-2019-ncov-on-11-february-2020 (May 3, 2020). 